\title{
Physio-Chemical Analysis of Industrial Effluents in parts of Edo States Nigeria
}

\section{${ }^{* 1}$ EWERE EE; ${ }^{2}$ OMOIGBERALE, MO; ${ }^{3}$ BAMAWO, OER; ${ }^{4}$ ERHUNMWUNSE, NO}

\author{
${ }^{1,2,3,4}$ Department of Animal and Environmental Biology, \\ Faculty of Life Sciences, University of Benin, Nigeria \\ *Corresponding Author:ewere_endurance@yahoo.com, endurance.ewere@uniben.edu
}

KEY WORDS: Physico-Chemical Analysis, Industrial Effluent, Edo State

\begin{abstract}
Water pollution, particularly, surface water results from all activities of man involving indiscriminate waste disposal from industry such as effluents into waterways, waste, agricultural waste, and all forms of man's activities that results in contamination of the surface water. Wastewater samples were collected from two (2) carefully selected industries and the Physico-Chemical parameters were analyzed and compared to FEPA (Federal Environmental Protection Agency) standard. DO of the analysis ranged from $6.5-$ $9.7 \mathrm{mg} / \mathrm{l}$, BOD value range from $3.2-8.8 \mathrm{mg} / \mathrm{l}$, there was no significant difference among study stations $(\mathrm{P}>0.05)$, TDS showed a high significant difference $(\mathrm{P}<0.001)$. The results obtained from the analysis indicated that the effluents from the industries were relatively treated as the contaminants sampled were within statutory limits. It was however observed that the effluent from this brewery was relatively treated. @ JASEM
\end{abstract}

\section{http://dx.doi.org/10.4314/jasem.v18 i2.18}

Introduction: Water pollution, particularly, surface water results from all activities of man involving indiscriminate waste disposal from industry such as effluents into waterways, waste, agricultural waste, and all forms of man's activities that results in contamination of the surface water. Pollution is caused when a change in the physical, chemical or biological condition in the environment harmfully affect quality of human life including other animals' life and plant (Lowel and Thompson, 1992; Okoye et al., 2002). Industrial, sewage, municipal wastes are been continuously added to water bodies hence affect the physico-chemical quality of water making them unfit for use of livestock and other organisms (Dwivedi and Pandey, 2002).

Industrial effluent is unwanted water generated from industrial activities and are inappropriately discharged into the environment or receiving stream. Its characteristics provide basic information about the integrity of the rivers and streams into which they are discharged (Kanu et al., 2006). Effluent discharge into the environment with enhanced concentration of nutrient, sediment and toxic substances may have a serious negative impact on the quality and life forms of the receiving water body when discharge untreated or partially treated (Forenshell, 2001; Schulz and Howe, 2003). Water pollution by effluent has become a question of considerable public and scientific concern in the light of evidence of their extreme toxicity to human health and to biological ecosystems (Katsuro et al., 2004). The occurrence of heavy of metals in industrial and municipal sewage effluents constitute a major source of the heavy metals entering aquatic media.

The world health organization (WHO, 2006) and other concerned organization including local organizations have established international standard of chemical bacteria quality for portable drinking water and other water uses as an aid to the improvement of safe sanity quality. Therefore, for evaluating present and future sustenance of the surface water for social-economic growth (since the pollution of water in a place can lead to the contamination of water body at other remote regions), the level or concentration of physico-chemical parameters which determines the use of particular water must be periodically monitored. This work was carried out to analyze the effluent discharged from industries and to compare the results with Federal Environmental Protection Agency (FEPA) permissible standard for industrial waste discharge.

\section{MATERIALS AND METHODS}

Description of Study Area: Edo State lies roughly between longitude 060 04'E and 060 43'E and latitude $05044^{\prime} \mathrm{N}$ and $07034^{\prime} \mathrm{N}$. Edo State has a tropical climate characterized by two distinct seasons: the wet and dry seasons. The wet season occurs between April and October with a break in August, and an average rainfall ranging from $150 \mathrm{~cm}$ in the extreme north of the State to $250 \mathrm{~cm}$ in the south. The dry season lasts from November to April with a cold harmattan spelling between December and January. The temperature averages about $25^{\circ} \mathrm{C}\left(77^{\circ} \mathrm{F}\right)$ in the rainy season and about $28^{\circ} \mathrm{C}\left(82{ }^{\circ} \mathrm{F}\right)$ in the dry 
season. The climate is humid tropical in the south and sub-humid in the north.

Samples Collection and Preparation: Wastewater samples were collected from two (2) carefully selected industries (station 1 and station 2). In station 1 effluent were channeled to the receiving water through a stationary underground pipe. While in station 2 a well-constructed concrete drainage was used to channel the effluent into the river. Station 1 and 2 is the point where the wastewater from the two breweries enters the river and samples were collected at the point of entering the river. Samples were collected in $250 \mathrm{ml}$ glass bottles for DO and BOD, also samples were collected in plastic bottles for other physico-chemical parameters, pre-cleaned by washing with non-ionic detergents and rinsed with distilled water. The DO was fixed with Winkler solution A and Winkler solution B and cooled till it got to the laboratory for analysis. Before sampling; the bottles were rinsed three times with the sample water before being filled with the sample. The actual samplings were done by dipping the sampling bottles at approximately $20-30 \mathrm{~cm}$ inside the discharge outlet. The samples were then transported in cooler boxes immediately to the laboratory for further analysis.

Physicochemical Analysis: All field meters and equipment's were checked and calibrated according to the manufactures specification, samples collected where analyzed for $\mathrm{pH}$, temperature, electrical conductivity Dissolved oxygen, organic matter, total dissolved solids (TDS), Total suspended solids (TSS), total solids (TS), organic carbon, chemical oxygen demand (COD), chlorinity, calcium, magnesium, sodium, potassium, ammonium, sulphate, nitrate, phosphate and bicarbonate, biological oxygen demand (BOD), Samples were analyzed according to, APHA, 1995; Boyd C. E., 1979; Gordon et al, 1994.

\section{RESULTS}

The results of effluents analysis from study stations is presented in Table 1.

The mean $\mathrm{pH}$ of effluent ranged from $5.2-6.6$ in both stations. The most acidic station however was in station 1 having a mean average $\mathrm{pH}$ of 6.5 . There was no significant difference $(\mathrm{P}>0.05)$ among the study stations.
The mean Electrical Conductivity valvues ranged from $75 \mu \mathrm{S} / \mathrm{cm}-840 \mu \mathrm{S} / \mathrm{cm}, 175 \mu \mathrm{S} / \mathrm{cm}$ - 2340 $\mu \mathrm{S} / \mathrm{cm}$ in station 1 and 2 respectively. The highest value was recorded in station $2(2340 \mu \mathrm{S} / \mathrm{cm})$ and the lowest value was recorded in station $1(75 \mu \mathrm{S} / \mathrm{cm})$. There was a high significant difference $(\mathrm{P}<0.01)$ in the mean values of conductivity among the study stations.

The mean salinity values ranged from $0.209 \mathrm{mg} / \mathrm{l}$ and $0.579 \mathrm{mg} / \mathrm{l}$ in station 1 and station 2 respectively.

The mean colour values ranged from 17.25 and 21.25 in station 1 and 2 respectively. The highest value was recorded in station 2 (35.1) and the lowest value was recorded in station 1 (7.4). There was no significant difference $(\mathrm{P}>0.05)$.

The turbidity range values for the two stations were $10.5-15.7$ NTU, $5.8-24.8$ NTU respectively. The turbidity values from the study were however not significantly different $(\mathrm{P}>0.05)$.

The mean Total suspended solids (TSS) range values for station 1 and 2 were recorded as $18.4-23.9 \mathrm{mg} / \mathrm{l}$ and $12.9-47.2 \mathrm{mg} / \mathrm{l}$ respectively. The TSS values obtained from the study stations had no significant difference $(\mathrm{P}>0.05)$. Total dissolved solids range values for both stations were recorded as $34.5-$ $430 \mathrm{mg} / \mathrm{l}$ and $119-1180 \mathrm{mg} / \mathrm{l}$ respectively. The TDS values obtained in the study stations show a high significant difference $(\mathrm{P}<0.001)$.

Dissolved oxygen fluctuates between $6.5-9.7 \mathrm{mg} / \mathrm{l}$. The highest value $9.7 \mathrm{mg} / \mathrm{l}$ was recorded in station 2 . There was no significant difference $(\mathrm{P}>0.05)$ among study stations.

Biological oxygen demand values recorded were in the range of $3.8-8.8 \mathrm{mg} / \mathrm{l}$ for both station 1 and 2 respectively. The average mean values for both stations were observed as $6.8-7.5 \mathrm{mg} / 1$. There was no significant difference $(\mathrm{P}>0.05)$ among the study stations.

Chemical oxygen demand values ranges from 61.6 $92.1 \mathrm{mg} / \mathrm{l}$ and $40.6-140.8 \mathrm{mg} / \mathrm{l}$ in station 1 and 2 respectively. There was no significant difference ( $\mathrm{P}>0.05)$ among study stations. Alkalinity was taken as $\mathrm{HCO}_{3}$ with values ranging from $40.7-238 \mathrm{mg} / \mathrm{l}$ and $13.0-780 \mathrm{mg} / \mathrm{l}$ in station 1 and 2 respectively. 
Table 1: Physio-Chemical Parameter Chi-Square Test Was Used To Analyzed the Test of Significant

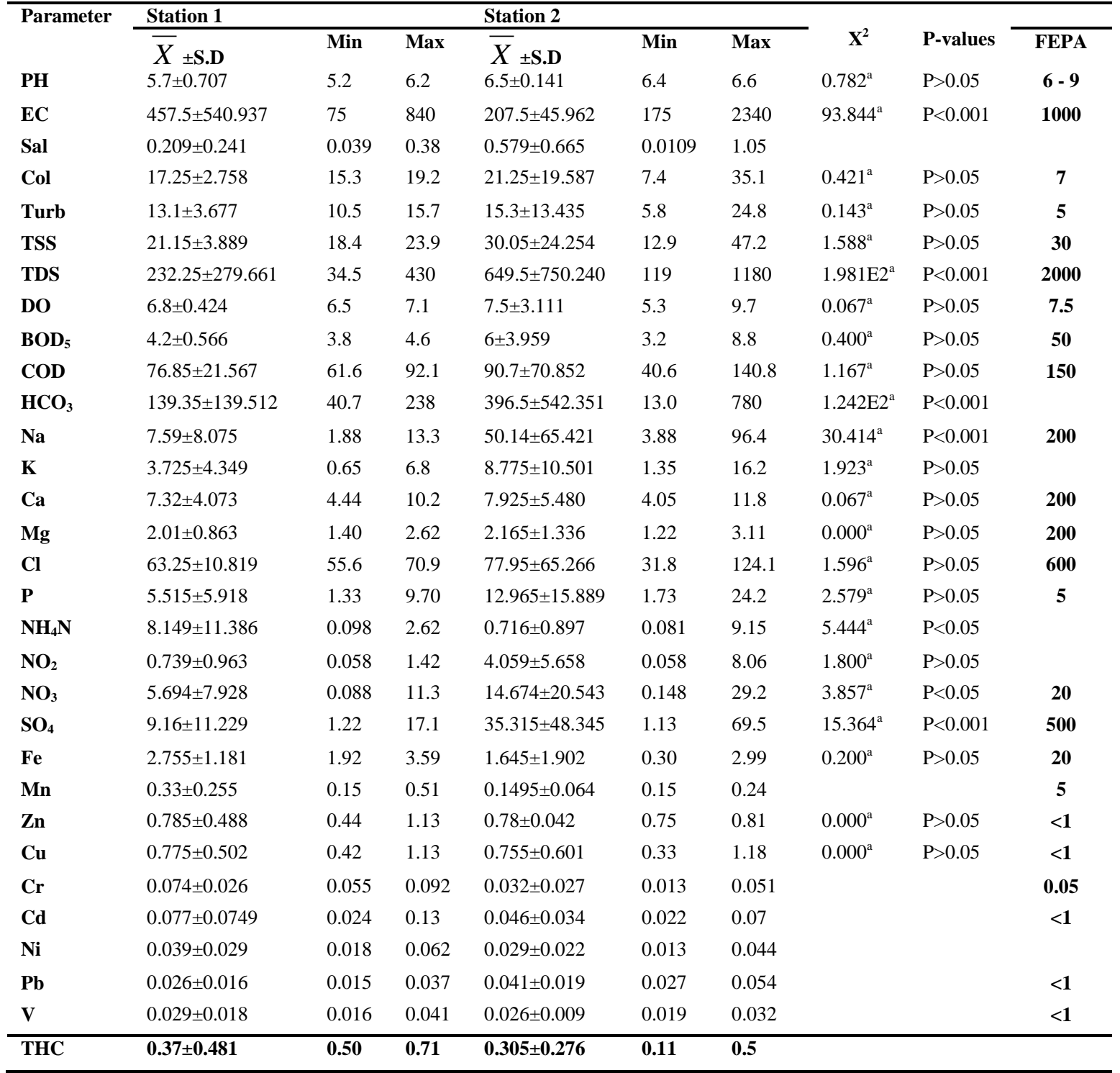

Note:

$\mathrm{P}<0.001-\quad$ Very highly significantly different

$\mathrm{P}<0.05 \quad$ - $\quad$ Highly significantly different

$\mathrm{P}>0.05 \quad$ - $\quad$ Not significantly different

Key: $\mathrm{THC}=$ Total hydrocarbon content, EC=Electrical Conductivity, Turb=Turbidity, TSS=Total Suspended Solids, TDS=Total Dissolved Solids, DO=Dissolved Oxygen, BOD=Biological Oxygen Demand, $\mathrm{COD}=$ Chemical Oxygen Demand, $\mathrm{Col}=$ Colour

Range values of sodium for both stations were recorded as $1.88-13.3 \mathrm{mg} / \mathrm{l}$ and $3.88-96.4 \mathrm{mg} / \mathrm{l}$ in station 1 and 2 respectively. The highest value in station was recorded as $13.3 \mathrm{mg} / \mathrm{l}$ and in station 2 as $96.4 \mathrm{mg} / \mathrm{l}$. There was a highly significant value observed $(\mathrm{P}<0.001)$ among study stations. Potassium highest value was recorded as $6.8 \mathrm{mg} / \mathrm{l}$ in station 1 and $16.2 \mathrm{mg} / \mathrm{l}$ in station 2 . There was no significant difference $(\mathrm{P}>0.05)$ among study stations. Calcium values in Station 1 and 2 ranged $4.44-10.2 \mathrm{mg} / \mathrm{l}$ and $4.05-11.8 \mathrm{mg} / \mathrm{l}$ respectively. The lowest value for calcium in station 1 was recorded as $4.44 \mathrm{mg} / 1$ and for station 2 as $4.05 \mathrm{mg} / \mathrm{l}$. There was no significant difference $(\mathrm{P}>0.05)$ among study stations. The minimum and maximum values of magnesium for both station 1 and 2 were recorded as $1.40-2.62 \mathrm{mg} / \mathrm{l}$ and $1.22-3.11 \mathrm{mg} / \mathrm{l}$ respectively. Highest value for magnesium recorded were $2.62 \mathrm{mg} / \mathrm{l}$ and $3.11 \mathrm{mg} / \mathrm{l}$ in station 1 and 2 respectively. There was however, no significant difference $(\mathrm{P}>0.05)$ in the mean values of magnesium content in the study stations. Chlorine content values ranged from $55.6-70.9 \mathrm{mg} / 1$ and 31.8 - 124.1mg/l in station 1 and 2 respectively. There was no significant difference $(\mathrm{P}>0.05)$ among the 
study stations. The values of phosphate ranged from $1.33-9.70 \mathrm{mg} / \mathrm{l}$ and $1.73-24.2 \mathrm{mg} / \mathrm{l}$ in station 1 and 2 respectively. There was no significant difference $(\mathrm{P}>0.05)$ in the mean value of phosphate in study stations. Average mean value for ammonia content ranged from $8.149 \mathrm{mg} / \mathrm{l}$ and $0.716 \mathrm{mg} / \mathrm{l}$ in station 1 and 2 respectively. Minimum and maximum value in both study stations were recorded as $0.098-2.62 \mathrm{mg} / \mathrm{l}$ and $0.081-9.15 \mathrm{mg} / \mathrm{l}$. There was a highly significant value $(\mathrm{P}<0.05)$ among the study stations. Average mean value for nitrous oxide content ranged from $0.739 \mathrm{mg} / \mathrm{l}$ and $4.059 \mathrm{mg} / \mathrm{l}$ in both station 1 and 2 respectively. Minimum and maximum value range from $0.058-1.42 \mathrm{mg} / \mathrm{l}$ and $0.058-8.06 \mathrm{mg} / \mathrm{l}$ in both stations respectively. There was no significant difference $(\mathrm{P}>0.05)$ among the study stations. Nitrate values ranged from $0.088-11.3 \mathrm{mg} / \mathrm{l}$ and $0.148-$ $29.2 \mathrm{mg} / 1$ in both station 1 and 2 respectively. The mean average of nitrate in both stations was observed as $5.694 \mathrm{mg} / \mathrm{l}$ and $14.674 \mathrm{mg} / \mathrm{l}$. There was highly significant difference $(\mathrm{P}<0.05)$ among the study stations. Sulphate Values ranged from $1.22-$ $17.1 \mathrm{mg} / \mathrm{l}$ and $1.13-69.5 \mathrm{mg} / \mathrm{l}$ in station 1 and 2 respectively. The mean average of Sulphate was observed as $9.16 \mathrm{mg} / \mathrm{l}$ and $35.315 \mathrm{mg} / \mathrm{l}$ in station 1 and 2 respectively. The Sulphate values shows very highly significance $(\mathrm{P}<0.001)$ among study stations.

The values ranged recorded for iron in both station 1 and 2 were $1.92-3.59 \mathrm{mg} / \mathrm{l}$ and $0.30-2.99 \mathrm{mg} / \mathrm{l}$ respectively. The highest value was recorded in station $1(3.59 \mathrm{mg} / \mathrm{l})$ and the lowest in station 2 $(2.99 \mathrm{mg} / \mathrm{l})$. There was no significant difference $(\mathrm{P}>0.05)$ in the mean values of iron content in the study stations. Manganese range values for station 1 and 2 are $0.15-0.51 \mathrm{mg} / \mathrm{l}$ and $0.15-0.24 \mathrm{mg} / \mathrm{l}$ respectively. The highest mean average was recorded in station $1(0.33 \mathrm{mg} / \mathrm{l})$ and lowest in station 2 $(0.1495 \mathrm{mg} / \mathrm{l})$. The minimum and maximum value range of zinc in station 1 and 2 was recorded as 0.44 $-1.13 \mathrm{mg} / \mathrm{l}$ and $0.75-0.81 \mathrm{mg} / \mathrm{l}$ respectively. The mean average was recorded as $0.785 \mathrm{mg} / 1$ and $0.78 \mathrm{mg} / \mathrm{l}$ in both station 1 and 2 respectively. There was no significant difference $(\mathrm{P}>0.05)$ in the mean values of zinc content in the study stations. Station 1 and 2 had range values of $0.42-1.13 \mathrm{mg} / \mathrm{l}$ and 0.33 $1.18 \mathrm{mg} / \mathrm{l}$ respectively for copper. The mean average was recorded as $0.775 \mathrm{mg} / \mathrm{l}$ and $0.775 \mathrm{mg} / \mathrm{l}$. There was no significant difference $(\mathrm{P}>0.05)$ in the mean values of copper content in the study stations. The range value recorded for chromium in station 1 and 2 were $0.055-0.092 \mathrm{mg} / \mathrm{l}$ and $0.013-0.051 \mathrm{mg} / \mathrm{l}$ respectively. The mean observed for both stations was recorded as $0.074 \mathrm{mg} / \mathrm{l}$ and $0.032 \mathrm{mg} / \mathrm{l}$ in station 1 and 2 respectively.

The range value recorded for chromium in station 1 and 2 was $0.024-0.13 \mathrm{mg} / \mathrm{l}$ and $0.022-0.07 \mathrm{mg} / \mathrm{l}$ respectively. The mean for both stations was recorded as $0.077 \mathrm{mg} / 1$ and $0.046 \mathrm{mg} / 1$. Nickel had range values of $0.018-0.062 \mathrm{mg} / \mathrm{l}$ and $0.013-0.044 \mathrm{mg} / \mathrm{l}$ in both station 1 and 2 respectively. The mean was recorded as $0.039 \mathrm{mg} / \mathrm{l}$ and $0.029 \mathrm{mg} / \mathrm{l}$ in station 1 and 2 respectively.

Lead had range values of $0.015-0.037 \mathrm{mg} / \mathrm{l}$ and $0.027-0.054 \mathrm{mg} / \mathrm{l}$ in station 1 and 2 respectively. The mean of the study stations were recorded as $0.026 \mathrm{mg} / \mathrm{l}$ and $0.041 \mathrm{mg} / \mathrm{l}$ respectively. Vanadium had range values of $0.016-0.041 \mathrm{mg} / 1$ and 0.019 $0.032 \mathrm{mg} / \mathrm{l}$ respectively in both station 1 and 2 . Total hydrocarbonIt had range values of $0.50-0.71 \mathrm{mg} / \mathrm{l}$ and $0.11-0.54 \mathrm{mg} / \mathrm{l}$ respectively in both station 1 and 2. The mean average of the study stations were recorded as $0.37 \mathrm{mg} / \mathrm{l}$ and $0.305 \mathrm{mg} / \mathrm{l}$ for station 1 and 2 respectively.

\section{DISCUSSION}

The problems associated with the dispersal of industrial and urban wastes generated by human activities are the contamination of the soil, controlled and uncontrolled disposal of wastes, accidental and process spillage, mining and smelting of metalliferous ores and sewage sludge application to agricultural soils.

The range values of $\mathrm{pH} 5.2-6.2,6.4-6.6$ was recorded in station 1 and 2 respectively. The low $\mathrm{pH}$ of 5.2 at the contact point which is acidic can be attributed to the concentration of the waste coming out of the station, and were not within the FEPA regulatory unit of 6--9 set for discharge into surface water. The acidic nature of an industrial effluent is capable of stemming the $\mathrm{pH}$ of their respective receiving water bodies thereby, destabilizing fundamental properties such as alkalinity, metal solubility and hardness of water. High $\mathrm{pH}$ in African rivers have earlier been recorded by various workers (Egborge A. B. M,et.,al 1986; Fufeyin P. 1987; Ogbeibu AE, et.,al 1989) indicating that water is moderately acidic with little fluctuations in $\mathrm{pH}$ values recorded.

Electrical conductivity (EC) is a measure of the total ionic composition of water and therefore its overall chemical richness. It is primarily determined in water by the presence and levels of concentration of sodium and magnesium ions and to some extent calcium ions. Their ions help buffer the effect of bicarbonate and carbonate ions, thus maintaining the $\mathrm{pH}$. The EC of the water samples ranged with lowest mean average in station 2 as $207.5 \mu \mathrm{S} / \mathrm{cm}$ and highest recorded in station 1 as $457.5 \mu \mathrm{S} / \mathrm{cm}$, there was a high significant difference $(\mathrm{P}<0.01)$ in the mean values of conductivity among the study stations. The EC of water is a useful and easy indicator of its salinity or total salt content. In the present study the salinity values are less than $1000 \mu \mathrm{S} / \mathrm{cm}$ set by the FEPA (FEDERAL ENVIRONMENTAL PROTECTION AGENCY). 
It is known that calcium and magnesium along with their carbonates, sulphates and chlorides naturally confer temporary and permanent hardness. Water having $0-75 \mathrm{mg} \mathrm{CaCO}_{3}$ was describe as soft, 75$15075 \mathrm{mg} \mathrm{CaCO}_{3}$ as hard water while samples having total hardness of over $300 \mathrm{mg} \mathrm{CaCO}_{3} \mathrm{~L}$ as hard according to Adeyeye and Abulude (2004). Samples of water collected at various points and brewery effluent samples were below hard water concentration limits, as the amount of calcium and magnesium was low as compared within the FEPA permissible limit of $200 \mathrm{mg} / \mathrm{l}$. The low values of calcium and magnesium in the various samples collected from the effluent may have resulted from the rapid dissolution of calcium and magnesium in the flowing effluent into open waters.

Total suspended solids (TSS) mean range from $21.15 \mathrm{mg} / \mathrm{l}$ to $30.05 \mathrm{mg} / \mathrm{l}$ respectively. The value obtained from wastewater collected in station 2 as 30.5 was slightly above $30 \mathrm{mg} / \mathrm{l}$ permissible limit set by FEPA. If this waste water is applied directly to agricultural field or discharged into rivers and stream, this could make it unsuitable for aquatic life. For the total dissolved solids (TDS), values obtained for all samples assayed were within the permissible limit set by FEPA.

Polluted water contains low levels of dissolved oxygen (DO) as a result of heavy biological oxygen demand(BOD) and chemical oxygen demand(COD) placed by effluent discharged into surface water. This makes water unsuitable for drinking and irrigation (Hari et al., 1994) or any other use. Lowest mean for DO concentration was recorded in station 1 as $6.8 \mathrm{mg} / \mathrm{l}$. The mean value for COD observed were $76.85 \mathrm{mg} / 1$ in station 1 with highest mean value recorded in station 2 as $90.7 \mathrm{mg} / \mathrm{l}$ but was below the $150 \mathrm{mg} / \mathrm{l}$ set by FEPA. The biological oxygen demand (BOD) and chemical oxygen demand (COD) are useful parameters in water quality analysis. BOD and COD are both a function of DO; decrease in DO will lead to increases in BOD and COD values. Ipeayada and Onianwa, suggest that brewery effluent samples on entering nearby stream or river will cause oxygen depletion and may cause suffocation of fish and other aquatic organisms.

Heavy metals are inorganic elements essential for plant growth in trace amount, toxic in relatively higher concentrations (Egborge, 1994). These heavy metals are not biologically degradable (Ezemonye, 1992). This was observed in the study stations. The heavy metals tested for; $\mathrm{Fe}, \mathrm{Mn}, \mathrm{Cr}, \mathrm{Ni}, \mathrm{V}$ which shows very low concentration and was within the limits set by FEPA as shown in Table 1. Lead $(\mathrm{Pb})$ was detected in the brewery effluent samples with mean average $0.026 \mathrm{mg} / \mathrm{l}$ in station 1 and 0.041 in station 2. The concentration of $\mathrm{Pb}$ obtained for the brewery effluent samples $(0.041 \mathrm{mg} / \mathrm{l})$ was slightly below permissible limit of 0.05 set by FEPA.
The mean average of the concentrations of $\mathrm{Mn}$ in both station 1 and 2 were recorded as 0.33 $0.1495 \mathrm{mg} / \mathrm{l}$ respectively and were below the permissible limit of $5 \mathrm{mg} / \mathrm{l}$ set by FEPA. While the mean average concentration of $\mathrm{Zn}$ were recorded as $0.785-0.780 \mathrm{mg} / \mathrm{l}$ in both station 1 and 2 respectively which was higher than the permissible limit of $0.1 \mathrm{mg} / 1$ set by FEPA Station 1 and 2 had range values of copper as $0.42-1.13 \mathrm{mg} / \mathrm{l}$ and 0.33 $1.18 \mathrm{mg} / 1$ for both stations respectively as this was observed to be higher than the permissible limit set by FEPA.

Conclusion: Although to a very large extent, by comparing the physicochemical quality of effluent as a result of industrial processes, one can conclude if actually the quality of the water body where it is discharged into was modified, the study however showed that contaminants sampled were within statutory limits. The water samples collected could not pose any environmental risk even when let into open waters. It was however observed that the effluent from this brewery was relatively treated.

\section{REFERENCES}

Adeyeye, E. I, Abulude, (2004). Analytical Assessment of some surface and groundwater resources in Ile-Ife, Nigeria. Journal of Chemical Society of Nigeria. 29:98-103.

Gordon, N. D., T. A Mc Mahon and BL Finlayson, Stream hydrology, an introduction for ecologist. New York,John Wiley and Sons, 1994; pp. 526.

Dwivedi, B. K. and Pandey, G. C. (2002). Physicochemical factors and algal diversity of two ponds In Faizabad, India. Poll. Res. 21(3):361-370.

Egborge, A. B. M. (1994). Biodiversity and chemistry of Warri River. In: water pollution in Nigeria, (vol.1) Ben miller books, Nigeria limited, pp.331.

Egborge, A. B. M. (1986). Water quality index Application in Warri. Environmental Pollution Biology 12: 7 - 40.

Egborge, A. B. M., Okoro, J. I., Alawani, O. A. and Uraih, N. (1986). Thermal and Chemical pollution of Benin River and its tributary the Jamieson River in Nigeria. Nigeria Journal ofApplied Science. 4:121-149.

Federal Environmental Protection Agency (FEPA). (1991). Guidelines to Standards for Environmental Pollution Control in Nigeria, FG Press Lagos Nigeria. Pp.238. 
Forenshell, G. (2001). Setting basin design. Western Regional Aquaculture Center, WRAC-106. USA: $6 \mathrm{pp}$

Fufeyin, P. (1987). Studies on The Fish Community of Benin River to Evaluate The Effects of Warm Water Effluents Discharged By the NEPA Station at Sapele, Bendel State,

M.Sc Thesis, University of Benin, Benin City, Nigeria. Pp.101.

Katsuro, A., Yashiko, K., Yoshinnori, S., Takashi, T., and Hayao, S. (2004). Heavy - metal

Distribution in River Waters and sediment a firefly village, Shikou, Japan: Application of multivariate Analysis. Analytical science, 20: 7984.

Lowel and Thompson F., (1992). Biodiversity of vibrios. Microbiol. Mol. Biol. Rev. 68: 403-431.

Ogbeibu, A. E. and Victor, R. (1989). The Effect of Road and Bridge Construction on the bank root macroinvertebrates of a Southern Nigeria stream. Environmental Pollution. 56:85100

Okoye, P. A. C., Enemuoh, R. E. and Ogunjiofor, J. C. (2002). Traces of heavy metals in Marine crabs. J. Chem. Soc. Nigeria. 27 (1) 76-77
Schulz, K. and Howe, B. (2003). Uncertainity and sensistivity analysis of water transport modeling in a layered siol profile using fuzzy set theory. $J$. Hydroinform., 1: 127-138.

\section{UNITED NATION ENVIRONMENTAL}

PROTECTION (UNEP) and WORLD HEALTH ORGANIZATION (WHO) (1996). Water Quality Monitoring. An imprint of chapman and Hall, London.

WORLD HEALTH ORGANIZATION (1993).

Guideline for Drinking Water Quality Recommendation (2nd ed). World Health Organization, Geneva Switzerland.Pp.12.

Boyd, C. E. (1979). Water Quality in Warm Water Fish Ponds. University Press, Alabama, USA, pp: 59.

APHA, (1995): Standard Methods for Examination of Water and Wastewater, 19th Edition, American Public Health Association, Washington, USA. 1993. 